\title{
Toxicity Bacillus thuringiensis-based Bio Insecticide Enriched with Golden Snail Meat Flour Against Worker and Soldier Castes of Coptotermes Curvignathus Termitidae)
}

\author{
Yulia Pujiastuti ${ }^{1}$ \\ ${ }^{1}$ Dept. of Plant Protection, Faculty of Agriculture, Universitas Sriwijaya, Indonesia
}

\begin{abstract}
Subterrane an termites Coptotermes curvignathus are important pests in plantation crops, especially rubber and oil palm. Biological control using entomo pathogenic bacteria Bacillus thuringiensis is safe and ecofriendly. The aim of study was to investigate production of B. thuringiensis propagated in media of coconut water and rice washed water enriched with golden snail meat flour as well as its toxicity to soldier caste and worker termites. The study was carried out at Biological Control Laboratory, Department of Plant Protection Faculty of Agriculture, Sriwijaya University, from May to August 2018. The research was arranged with a Completely Randomized Design (CRD) with addition of golden snail meat flour treatment i.e. $2,5,8,11,14 \mathrm{~g}$ respectively and without any meat flour addition in media Nutrient Broth as a control. The highest spore density obtained will be used for bioassays toward worker caste, soldier caste and a mixture of them. The results showed highest spore density was obtained at meat flour addition of 14 g i.e. $5.58 \times 10^{7}$ spores $/ \mathrm{ml}$. In toxicity test, it was found that mortality of soldier caste was higher in the treatment without being mixed with worker caste. Many soldiers have large heads with highly modified powerful jaws so enlarged they can not feed themselves. Instead, like juveniles, they are fed by workers.
\end{abstract}

\section{Introduction}

Subterranean termites are pests in several types of plantation crops. Well known in rubber plantation, Coptotermes curvignathus is an important pest that must be controlled [1]. Control of termites using chemical pesticides must be done wisely after the recommended target, time and dosage. Otherwise, there will be pollution to the soil and the local environment. Therefore, a biological control method is proposed [2] by using entomopathogenic bacterium Bacillus thuringiensis. These bacteria are gram positive and produce spores and proteins that are toxic to insect pests [3]. Mode of action of this bacterium is through digestion of food or stomach poisons. If the protein spores and/or crystals are swallowed by the larvae, and reach the middle intestine (midgut), the protein crystals that are still in the form of protoxins will be stimulated by the protease enzyme to 
produce an active toxin with a molecular weight of about $60 \mathrm{kDa}$. This toxin is called deltaendotoxin. The toxin will then be bound in the receptor cells contained in the midgut, the attachment resulting in the formation of pores or holes in the cell and cause ion imbalance. The larvae will become inactive, stop eating, vomiting, or the stool becomes runny. The head of the insect will look too large compared to its size. These bacteria will cause the insect's body to become brownish-black, red, or yellow, and rot [3,4].

In $B$. thuringiensis propagation, suitable growth media are needed, with certain requirements such as carbon: nitrogen ratio $=1.26: 1$ in Luria Bertani broth [5] . Furthermore, the addition of other organic ingredients can be used as boosters in the production of spores and proteins. Enrichment of B. thuringiensis growth media with the addition of cell growth boosters is quite important. Based on the experience of [6] the addition of golden snail meat flour as much as $10 \%$ in growing media, can increase bacterial cell growth and improve its pathogenicity. In addition, the nutritional content of gold snail is high enough consisting of protein and B vitamins, especially vitamin B2, which functions as a calorie enhancer. Nutritional content of golden snail meat flour is $51.8 \%$ crude protein, $13.61 \%$ crude fat, fiber rough $6.09 \%$ and ash content $24 \% C$. curvignathus is an eusocial insect that has a caste system in its life. It is known 3 castes namely reproductive caste, worker caste and soldier caste [7]. The population of workers caste dominates in the colony that is as much as 80 percent while the rest are the caste of soldiers and reproductive caste. Reproductive caste consists of several fertile males (as king) and usually one female as queen. Worker castes and soldier castes are completely blind as they don't have a pair of eyes. Termite antenna has a number of functions such as sensing of touch, taste, odors (including pheromones), heat and vibration [8,9]. The purpose of this research is to investigate production of $\mathrm{B}$. thuringiensis propagated in media of coconut water and rice washed water enriched with enrichment of golden snail meat flour as well as its toxicity to soldier caste and worker termites.

\section{Materials and Methods}

The study was carried out at the Biological Control Laboratory, Department of Plant Protection Faculty of Agriculture, Sriwijaya University, from May to August 2018. B. thuringiensis isolates used were collection isolates of the Laboratory of Biological Control, Department of Plant Protection Agricultural Faculty, Sriwijaya University. The isolate originale isolated from soil in Sekayu District South Sumatera namely KJ3R5 isolate [10]. Termites were obtained from oil palm plantation of Agricultural Faculty of UNSRI Indralaya campus.

The research was arranged in a Completely Randomized Design (CRD) with the addition of golden snail meat flour (GSM) treatment. 2, 5, 8, 11, $14 \mathrm{~g}$ respectively and without any meat flour addition in Nutrient media Broth as a control. The highest density of spores will be used as bio insecticide against termites, with three applications i.e. worker, soldier and worker + soldier (Table 1). 
Table 1. Treatments used in the experiment

\begin{tabular}{|c|c|}
\hline Addition of GSM into stock solution & Application to termites \\
\hline $\mathrm{P} 2=2 \mathrm{~g} \mathrm{GSM}$ & $\mathrm{T} 0$ :worker \\
\hline $\mathrm{P} 5=5 \mathrm{~g} \mathrm{GSM}$ & $\mathrm{T} 1:$ soldier \\
\hline $\mathrm{P} 8=8 \mathrm{~g} \mathrm{GSM}$ & $\mathrm{T} 2$ :worker and soldier \\
\hline $\mathrm{P} 11=11 \mathrm{~g} \mathrm{GSM}$ & \\
\hline $\mathrm{P} 14=14 \mathrm{~g} \mathrm{GSM}$ & \\
\hline Control $(0) \mathrm{g} \mathrm{GSM}$ & \\
\hline
\end{tabular}

\subsection{Preparation of Golden Snail Meal (GSM)}

Golden snails were collected from swampy land surrounding Pemulutan Ulu, SubDistrict of Pemulutan, Ogan Ilir District. The snails were placed in a plastic bucket of 50 $\mathrm{cm}$ height and $30 \mathrm{~cm}$ in diameter and were soaked in water. The snails were fasted for 48 hours to make them clean. The snails were then washed and cooked in water for 15-20 minutes. After being cooled, the snail flesh was separated from the shell and digestion organs. The flesh was then grilled in an oven at $80^{\circ} \mathrm{C}$ for 18 hours. The dried flesh was then served as a finisher meal of the snail flesh. The golden snail meal (GSM) was ready to be used to make bio-insecticide.

\subsection{Cell Production / spores of B. thuringiensis}

Preparation of growth medium was $50 \mathrm{ml}$ of coconut water and $50 \mathrm{ml}$ of rice washed water and golden snail flour according to the treatment was put into $250 \mathrm{ml}$ erlenmeyer, then added mineral salts following the procedure of Dulmage and Rhodes (1971) as much

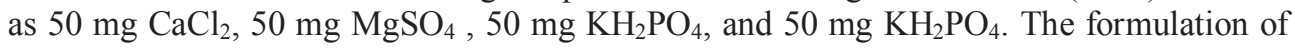
bio-insecticide was started with the preparation of seed culture[1] by placing one lope of $B$. thuringiensis Isolate of KJ3R5 in $10 \mathrm{ml}$ of Nutrient Broth (NB) media and was shaken for 12 hours at $200 \mathrm{rpm}$. Afterward, $5 \mathrm{ml}$ of culture was taken and transferred to $10 \mathrm{ml}$ of NB medium and was shaken for 12 hours at $200 \mathrm{rpm}$. Seed culture was ready to be used to make bio-insecticide. Furthermore, the bacterial growth media in the erlenmeyer is placed in a shaker and set at $200 \mathrm{rpm}$. During the next 24 hours, the shaker is stopped to take a sample of $1 \mathrm{ml}$ aseptically. The number of cells / spores was calculated by using haemocytometer and recorded. During the next 48 hours one $\mathrm{ml}$ sample is taken aseptically to check the number of spores. At 72 hours, shaker is stopped. Spores were recalculated and then $B$. thuringiensiswas ready to be used for bioassay testing. Bioassay of cell and spores of $B$. thuringiensis towards Coptotermes curvignathusObservation of density of spores by haemocytometer will resulted the highest spore density in certain treatments. Bioassay test was carried out by using this density of spores. Each treatment was replicate 5 times in which every replication provided 30 individues of termites, including worker caste $(\mathrm{T} 0=30$ heads), soldier caste ( $\mathrm{T} 1=30$ heads) and a mixture of the two castes ( $2=15$ workers and 15 soldiers). The application method is by spraying B. thuringiensis-based bio insecticides on the soil where termites live. Observations are carried out starting from the first 24 hours to the fifth day. Recorded the number of died termites. Insect mortality was determined by using the following formula:

Mortality $(\%)=($ number of dead larvae $) /($ number of larvae observed $) \times 100 \%$ 


\section{Results and Discussions}

\subsection{Spore Density.}

B. thuringiensis isolate used was $\mathrm{Bt}$ with isolate code KJ3R5 which has a protein molecular weight of 45-80 $\mathrm{kDa}$. From the previous results it was found that the isolate was able to kill the third instar larvae of armyworm Spodotera litura until 86.67\% [11]. Therefore, this isolate was chosen to be propagated with agricultural and household waste materials and tested on an important pest in rubber plants $C$. curvignathus termites. From the propagation on coconut water and rice washed water and the addition of golden snail meat flour, it was known that data generally tends to increase in spore density starting from the first, second and third 24 hours. The complete data is presented in Figure 1.

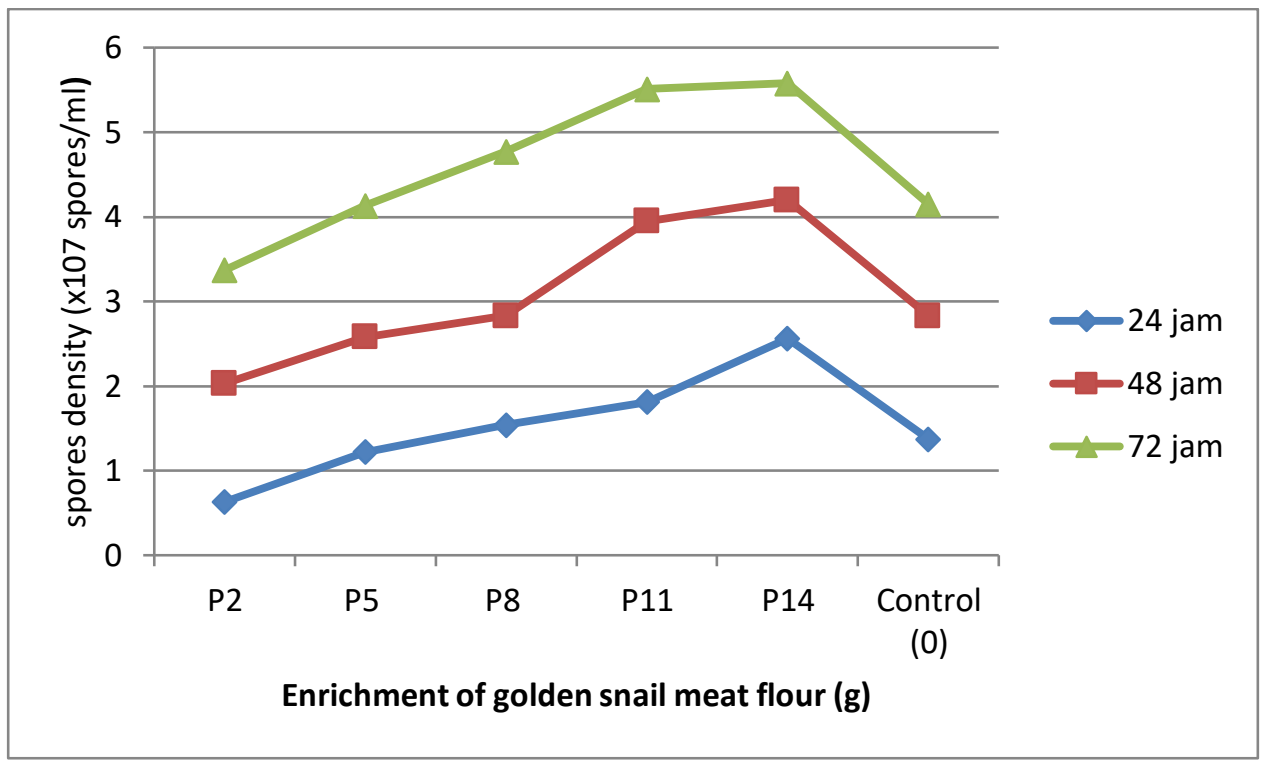

Fig. 1. Bacillus thuringiensis spore density by enrichment of golden snail meat flour (GSM)

Spore density in the first 24 hours was generally still low, except for the highest (P14) which was $2.56 \times 10^{7}$ spores $/ \mathrm{ml}$. In the period of 72 hours of shaking, the highest value of $5.58 \times 10^{7}$ spores / $\mathrm{ml}$ was obtained, in the P14 treatment which means the most GSM addition was $14 \mathrm{~g}$. The formation of spores by $B$. thuringiensis during cultivation is very important in the process of bio insecticide production. [11] reported that $B$. thuringiensis will form spores together with the formation of protein crystals which will later function as active ingredients as bioinsecticides. Therefore, the more spores formed are expected to increase the amount of crystalline protein produced, so that by looking at the number of spores formed, it can be used to determine the harvest time as an indicator that the product has been formed [12]. This is because protein crystals will lysis from the cell wall at the end of sporulation [13]. 


\subsection{Bioassay of Termite Workers and Soldiers}

Toxicity tests were carried out by separating worker termites (T0) and soldier termites (T1). Table 2 showed that worker termites were tested individually with $B$. thuringiensisbased bio-insecticides. The highest mortality of worker was on the third and fourth days (26.67\%). In a separate trial, the termite soldier experienced the highest mortality on the second day which was $40 \%$ followed by $23.33 \%$ on the fourth day.

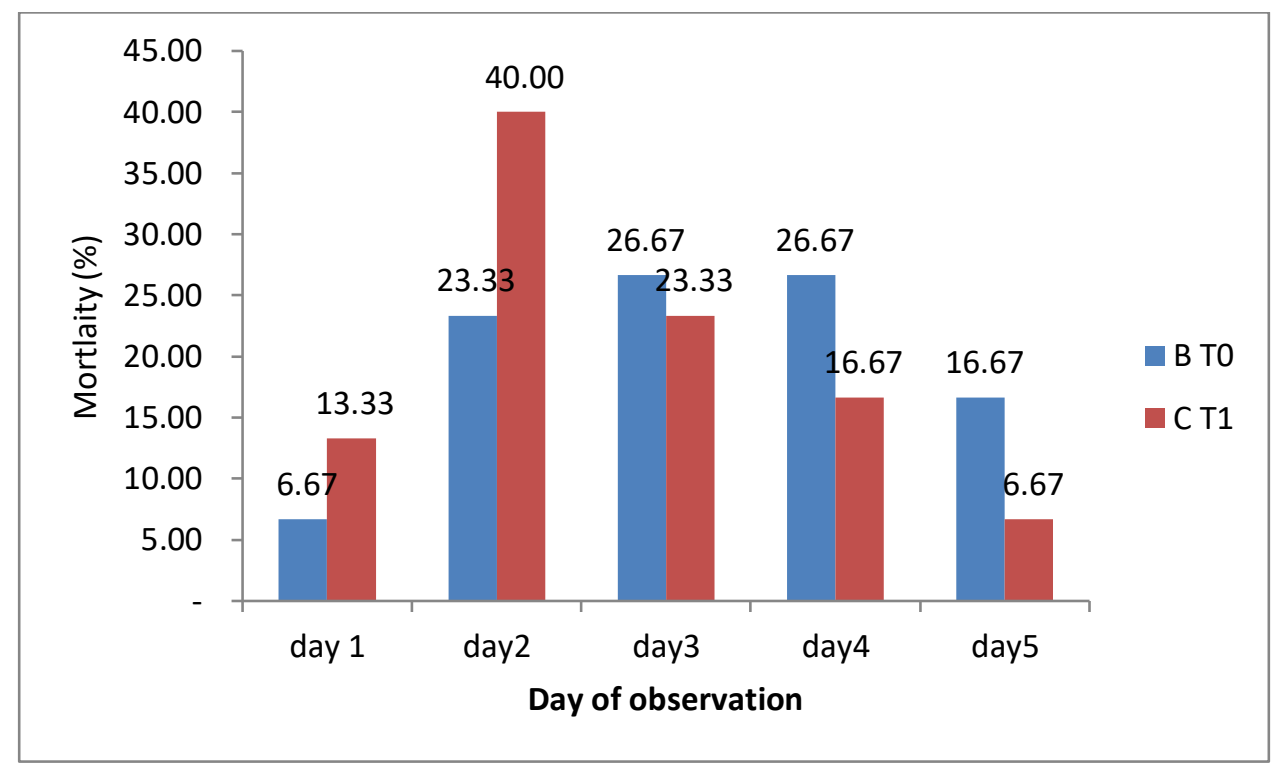

Fig. 2. Mortality (\%) of workers and soldiers in separate bioassay tests between workers (T0) and soldiers (T1) with treatment P14 (14 g)

The separation of each caste has an impact on the different mortality rates in the relevant caste. As it has been known that termite soldier have a characteristic change in the mandi blew here the shape becomes hardened in a clearer color (metallic orange) and has a function as a security guard for the colonies. Therefore, termite soldiers can not ful fill their own feed needs. In this case, termite workers have the duty to feed the queen / king and termite soldiers. Since they are unable to feed themselves, workers must feed them, but the social work of the people in particular and have certain tasks to do so, building or maintaining the nest or tending to the queen. When the soldier lives apart from the worker, the mortality rate of the soldier will be high. 


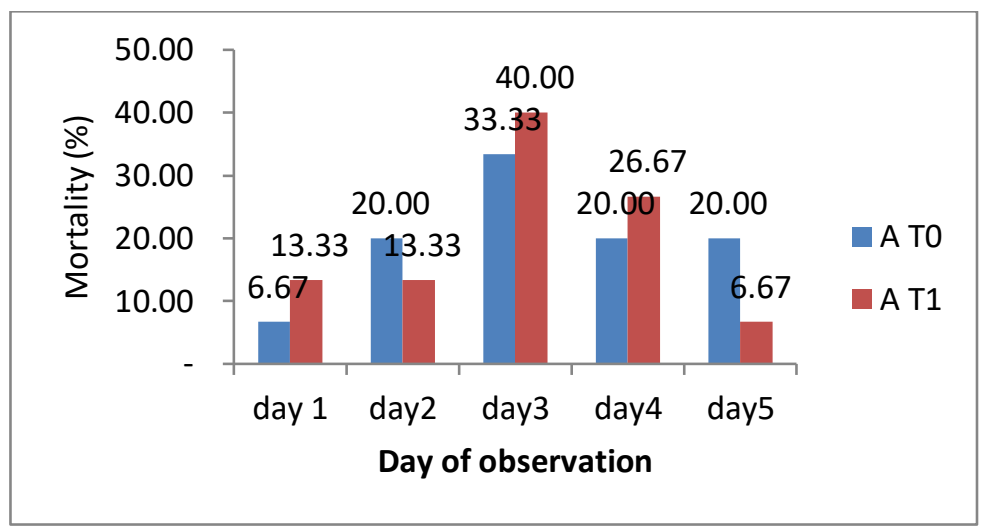

Fig. 3. Mortality (\%) of workers and soldiers in mixed bioassay tests between workers and soldiers in the treatment of golden snail meat flour $14 \mathrm{~g}$ enrichment

In the mixing treatment of test insects, namely $\mathrm{T} 2$ (termite workers and termite soldiers), it was found an interesting noccasion that the highest dead workers on the second day (Figure 1). However, soldier termites have a lower mortality rate (13.33\%) compared to the mortality of soldier termites in separate treatments. On the third day, the death rate of soldier termites was also high, this was allegedly due to the fewer number of termite workers so that only a few termite workers could feed the soldier termites. It issu spected that the presence of termite workers will help the termite soldiers to get their food directly bribed by worker termites. On the third day it was found that the death of termites only reached $16.67 \%$, where as on the fourth day and the fifth day there were no deaths of termites. This shows that there is a good cooperation between worker termites and termite soldiers where the help of worker termites is highly contrasted by soldier termites.

In nature, in the termite colony, their way of life is a social life where termite workers and termite soldiers together carry out their duties. Interaction between the moccurs in which the termite workers also have duty to feed the soldier termites [14]. In their research,[6]reports that the mortality of termite workers can occur first because workers' termites will consume food contaminated by $B$. thuringiensis, while termite soldiers will experience death in the next day after termite workers provide feed intake.

\section{Conclusion}

The addition of golden snail meat flour has an impact on the growth of B. thuringiensis bacteria, which is the highest density of spores at $14 \mathrm{~g}$ result edin $5.58 \times 107$ spores $/ \mathrm{ml}$. In the toxicity test, it was found that mortality reached $100 \%$ both in worker termites, soldier termites and applications in the mixture of both casts. Daily mortality rates varied, but in the treatment of separate termite soldiers from termite workers showed the highest mortality rate on the second day, because there were no termite workers will feed.

\section{Acknowledgments}

The author would like to thank Irmawati and Arsi who have helped in this research, especially in termite search. Thanks are also addressed to the Rector of Unsri who gave the opportunity to the author to carry out this research through the Unsri competitive grantin 2018 


\section{References}

1. Hill, D. S. Pests of Crops in Warmer Climates and Their Control, (United Kingdom, Springer Press, 2008)

2. Verma, M., S. Sharma, and R. Prasad, J. International Biodeterioration \& Biodegradation 63 (2009)

3. Bravo, A, S.Likitvivatanavong, S. Gillb, and M. Soberóna. J. Insect Biochemist. and Mol. Biol 41, 7 (2013)

4. Zhang, YuanGuilingZheng, JianxinTan,ChangyouLi,. J. Microbiological Research, 168 (2013)

5. Valicente H, Edgard P, Maria V, Newton C, Andréia C, Cláudia G and Ubiraci L. J. Biol Control 53 (2010)

6. Pujiastuti, Y., S. Masyitah, S. Dirgahayu, Suparman Shk, Effendy. The Use Of Golden Snail Meal To Enrich Bacillus Thuringiensis Culture Media And Its Effect On The Bacterial ToxicityAgainst Spodoptera Litura (JHPTT, In Press, 2018)

7. Watanabe, Dai., Hiroki Gotoh, Toru Miura and Kiyoto Maekawa. J. Frontiers in Phyisiology 5 (2014)

8. Costa-Leonardo and Haifig. Costa-Leonardo, A.M.; Haifig, I. J. Vitamins and Hormones 83 (2010)

9. Bignell DE, Roisin Y, Lo N. Biology of Termites: a Modern Synthesis (Springer, Dordrecht, Hardcover, ISBN: 978-90-481-3976-7, 2010)

10. Pujiastuti, Y. ' Dessy Tri Astuti, Siti Rakhmi, Suparman, Chandra Irsan, Enny Rimita Sembiring, Satya Nugraha, Nurhayati Damiri.J. Series: Earth and Environmental Science 102 (2017)

11. Federici B. A.Park H.-W.Bideshi D. K. J. Open Toxinol 3 (2010)

12. Schneider, M.F. Termite Life Cycle and Caste System" (University of Freiburg. Retrieved, 2015)

13. Purnawati, R, T.C. Sunarti, K. Syamsu, and M.Rahayuningsih. J. of Biol., Agric. and Healthcare 4, 16 (2014)

14. Wako, S. E. J. Ekológia (Bratislava) 34, 1 (2015) 